\title{
MEASURES TO REDUCE AIR POLLUTION CAUSED BY FUGITIVE DUST EMISSIONS FROM HARBOUR ACTIVITIES
}

\author{
SANDRA SORTE ${ }^{1}$, MYRIAM LOPES ${ }^{1}$, VERA RODRIGUES ${ }^{1}$, JOANA LEITÃO ${ }^{1}$, ALEXANDRA \\ MONTEIRO $^{1}$, JOÃO GINJA ${ }^{2}$, MIGUEL COUTINHO ${ }^{2}$, CARLOS BORREGO $^{1,2}$ \\ ${ }^{1}$ CESAM \& Department of Environment and Planning, University of Aveiro, Aveiro, Portugal \\ ${ }^{2}$ IDAD, Campus Universitario, Aveiro, Portugal
}

\begin{abstract}
Emissions from harbour-related activities have an important impact on air quality; therefore, improved knowledge about the coastal microclimate and consequent air pollution dispersion patterns is of utmost importance. In recent years, residents of the southeast urban community of the Port of Aveiro (Portugal) have identified high levels of dust in and around their residences, which has raised their concern regarding the potential effects of air pollution on public health. The citizens' complaints were linked to fugitive dust emissions from petroleum coke (petcoke), which is usually unloaded or temporarily stored outdoors in the port prior to transportation to a nearby manufacturing plant. Following this, the air quality measurements taken in the area have shown high levels of PM10 concentrations, especially when the wind blew from north and northwest directions. Furthermore, a numerical and physical modelling study has been performed in order to assess the impacts of the transport and storage of petcoke on the local air quality. The modelling results pointed out to a set of potential mitigation measures, namely the construction upwind of different barriers from the petcoke pile. This article presents the characterization of the problem and the management strategies adopted. It also presents the results of modelling assessment to select the most potential effective barrier in order to minimize petcoke dust impact on the surrounding population. Keywords: CFD model, mitigation measures, petcoke emissions, PM10 dispersion, mitigation measures, wind tunnel.
\end{abstract}

\section{INTRODUCTION}

Despite the progress achieved in the last few decades regarding air pollution control owing to the application of strict measures to reduce emissions, several European countries are still facing air pollution episodes with regular exceedances of the established legal limit values. Specifically, particulate matter concentrations remain one of the most critical air pollutants with severe effects threatening human health. Air pollutants dispersion is highly affected by climaterelated events. In coastal areas, where harbours and city ports are located, pollutants dispersion is mainly driven by the local sea-land breeze system. According to the European Sea Ports Organisation [1], the top environmental priority for sea ports is the local air quality, reflecting its importance to the health of port workers and nearby residents. With the projected increase of shipping activities, the air quality in and around ports will gain higher significance, especially in locations where the ports are surrounded by residential areas. Air pollutant emissions can be associated with several activities, not only those from ships, but also loading and unloading processes (particularly for solid bulk cargoes), outdoor storage of solid granules in piles, construction works and vehicles circulating on site (vehicular emissions and resuspension of road dust).

Petroleum coke (petcoke) is a granular residue derived from the refinement of crude oil into liquid fuels. Industrial combustion processes such as the energy-intensive cement manufacturing process use this material for energy production due to its low cost compared to coal [2]. A global demand for continuous supply of petcoke in a vast array of industries has, therefore, led to its frequent outdoor storage in stockpiles in the surroundings of urban and suburban 
areas. This often results in fugitive dust emissions from petcoke, which have potential negative health effects on local population. Moreover, petcoke particles may also have adverse impact on buildings [3]. The chemical composition of petcoke is variable and dependent on the quality of the crude oil from which it is obtained, with carbon being the main constituent with up to 91.8 wt. \%. Other components typically include hydrogen (up to 5.04 wt. \%), oxygen (up to 2.14 wt. \%), nitrogen (up to 1.2 wt. \%), sulphur (up to 3.42 wt. \%) and ash (up to 0.35 wt. $\%)$, which includes heavy metals, such as vanadium (V) or nickel (Ni) [2, 4]. Some toxicological studies have been performed $[3,5]$, suggesting that, in general, petcoke acts as an inert dust with human health risks associated to long-term dust inhalation, such as chronic pulmonary inflammation or respiratory tract irritation $[4,5]$. Additionally, particulate matter exposition, such as PM2.5 and PM10, i.e. particulate matter with diameters smaller than $2.5 \mu \mathrm{m}$ and $10 \mu \mathrm{m}$, respectively, is a well-established cause of lung and cardiovascular diseases due to inhalation and retention in the thoracic region of the respiratory system, with amplified effects on individuals with pre-existing lung or heart conditions as well as elderly people and children [6-8]. According to the European Environment Agency [7] components of solid PM such as metals or PAH (polycyclic aromatic hydrocarbons), which are contained in petcoke, are known carcinogens and directly toxic to living cells. As the reported studies indicate, there is still a lack of understanding concerning the health and environmental effects of fugitive petcoke dust and most the authors agree that further investigations are an important requirement [3].

Fuel grade high sulphur petcoke is the largest fuel market, accounting for almost $90 \mathrm{Mt}$, and its growth is expected to be approximately 3\% per year until 2020 [9]. Considering that global petcoke production continues to increase, the necessity for studies of health impact of this substance gains further significance. In 2010, Portugal was the 25th largest global importer of petcoke, with a total import volume of just over 155.8 US million dollars and between 2011 and 2013 the country has registered a 2.9\% growth in imports [10].

The seaport of Aveiro is one of the country's major petcoke entry points. Recently, residents of the southeast community of the seaport have claimed high levels of dust in and around their residences. The population concern and the potential link of high level concentrations to fugitive dust emissions from petcoke supported the port authority decision to investigate the dispersion of fugitive petcoke dust from its Solid Granulates Terminal (SGT) and evaluate the relevance of the implementation of control and mitigation measures.

This article presents an air quality management procedure applied to the seaport of Aveiro and the surrounding urban community. The procedure is based on air quality measurements, numerical and physical modelling. For that purpose, the air quality measurements campaigns and the main findings pointed out from the measured data analysis are presented. Furthermore, the results from the numerical and wind tunnel modelling are discussed showing potential emission reduction strategies to be adopted, mainly the implementation of an upstream barrier from the petcoke stockpile.

\section{CASE-STUDY FRAMEWORK}

The seaport of Aveiro is located in the small town of Gafanha da Nazaré (Aveiro district), with a SGT located at approximately $1 \mathrm{~km}$ north of the residential area (Fig. 1). Over the last few years, the residents of this suburban community (just under 15,000 inhabitants) have reported high quantities of petcoke dust in and around their residences, raising concerns of the potential effects on the health of local population. The seaport of Aveiro is one of the country's major petcoke entry points, due to its proximity to one of Portuguese largest cement production plants. The petcoke is usually unloaded and stored in stockpiles at the port's SGT and then transported by trucks to the cement plant of Souselas, which has an annual cement production capacity of $3.5 \mathrm{Mt}$ using petcoke as production fuel [11]. 


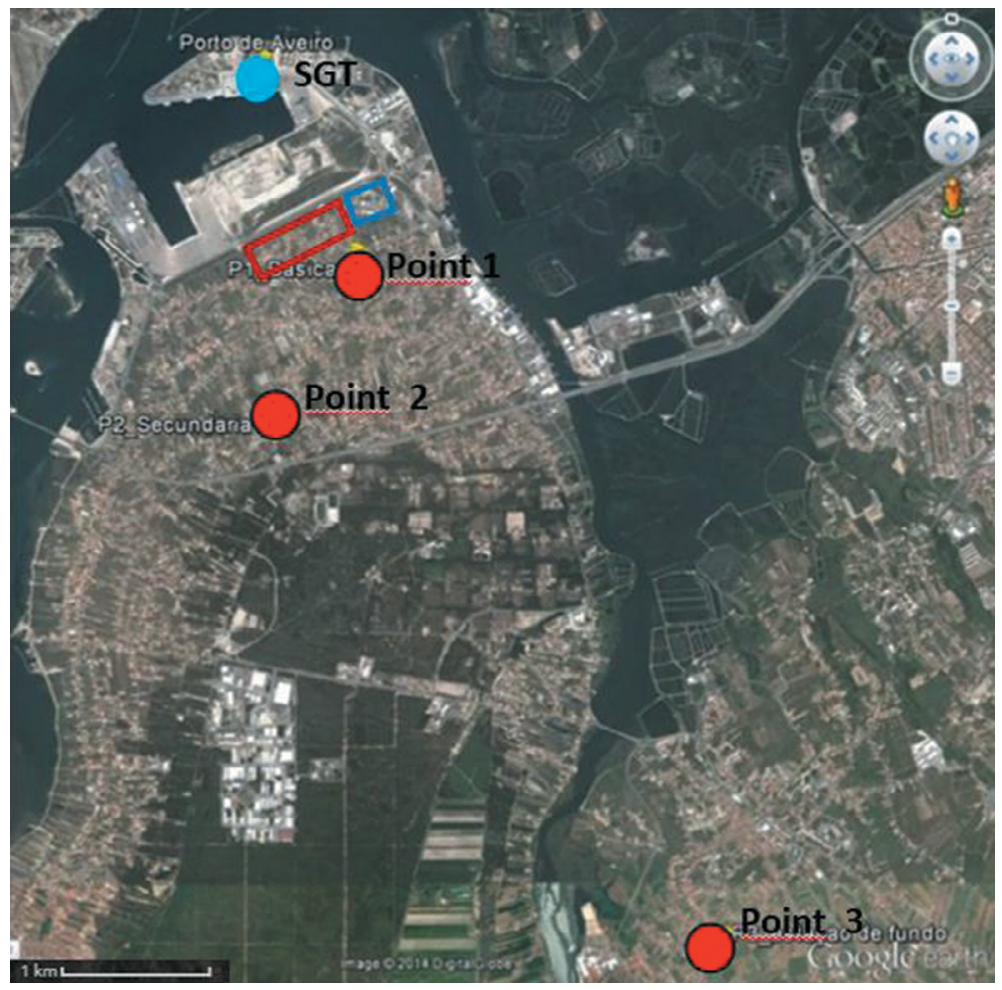

Figure 1: Map of the study area, with the town of Gafanha da Nazaré. The blue dot indicates the SGT $\left(40^{\circ} 39^{\prime} 15.63^{\prime \prime} \mathrm{N}, 8^{\circ} 42^{\prime} 59.83^{\prime \prime} \mathrm{O}\right)$, the red dotes P1, P2 and P3 indicate the air quality measurement points. The red square indicates the residential area located southeast of the seaport included in the modelling study, and the blue square indicates the industrial area.

The typical wind conditions of this area were assessed with an analysis of the measurements performed at $10 \mathrm{~m}$ high at meteorological tower located at University of Aveiro, roughly $5.5 \mathrm{~km}$ from the study domain. The meteorological data recorded between 2006 and 2013 was analysed. Typically, the most common wind directions are blowing from west-north and east-south quadrants, between northwest $(\mathrm{NW})$, north $(\mathrm{N})$ and southeast (SE) directions. In case of NW and N directions, the mean wind speed was ranging from $0.5 \mathrm{~m} . \mathrm{s}^{-1}$ up to $11 \mathrm{~m} . \mathrm{s}^{-1}$. The nearest residential area is located south and southeast of the harbour, downstream the prevailing winds.

\section{MITIGATION AND MANAGEMENT MEASURES}

Several technical and management measures can be adopted to reduce emissions and control the dispersion of air pollutants into the atmosphere. Nowadays, several ports and harbours have adopted appropriated environmental management plans to mitigate the adverse impacts of its activities [12]. The control and/or reduction of dust and particulate matter emissions from petcoke at the Port of Aveiro needs to consider the different operations involved from arrival to departure of the material: the unloading activity using a grab, the outdoor storage in piles, the loading of trucks or trains using tractor shovel, and the transport to its destination in heavy trucks or trains. 
The following actions could be considered additionally to the construction of fixed barriers $[12,13]$ :

- To spray water over the bulk material to control the fugitive emissions during loading and unloading processes

- To enclose the sources either fully or partially, if possible. In the case of Aveiro's port, covering the piles could prevent the dispersion of particulate matter

- To reduce the time of outdoor storage

- To transport bulk material in closed trucks and trains to avoid wind entrainment

- To clean regularly the paved and unpaved roads to reduce resuspension of dust

- To promote the increase of green spaces all around the port area to reduce air as well as noise pollution

Regular monitoring of air quality should be further strengthened to evaluate the effectiveness of air quality management plans. Simultaneously meteorological monitoring in the same sites could help to better understand local dispersion patterns and impacts in the surrounding areas [14].

To reduce the impact of petcoke dust emissions on local air quality, even before the implementation of the selected barrier configuration, the administration of the port of Aveiro (APA) implemented several good practices such as (i) spraying of water over the bulk material unloading from ships and loading heavy trucks; (ii) reducing the time of petcoke storage outdoors to decrease the rate of fugitive dust emissions; (iii) cleaning ground surfaces after temporary storage material has been removed and transported to final destination; (iv) reducing the size of the pile to decrease exposure to high wind speeds, and (v) altering the way petcoke is offloaded, releasing the petcoke closer to the ground.

\section{AIR QUALITY MONITORING}

In order to characterize air quality in the surroundings of the seaport, air quality measurement campaigns were carried out at 3 sites, $1.7 \mathrm{~km}$ southeast, $2.8 \mathrm{~km}$ south and $8 \mathrm{~km}$ southeast from the SGT (Fig. 1), and over three different periods: 2 July to 1 August 2014; 19 December 2014 to 20 January 2015; and 5 May to 4 June 2015. Several pollutants were measured, such as PM10, NOx, $\mathrm{SO}_{2}, \mathrm{CO}, \mathrm{C}_{6} \mathrm{H}_{6}, \mathrm{O}_{3}, \mathrm{PAH}$ and heavy metals such as chromium, copper, manganese, vanadium and zinc. Vanadium, zinc and nickel are usually associated with the emissions of petcoke $[3,5]$. During the measurement campaigns several arrivals of cargo ships carrying petcoke were registered, each one transporting between 6,000 and 10,000 tons. These amounts of petcoke were unloaded and stored in stockpiles at the SGT [15]. In general, the concentrations of the most of pollutants measured showed that the legislated standards of air quality were not exceeded, with only a few exceedances of $\mathrm{O}_{3}$ registered during the last period of measurements. Still, for PM10, high values were registered with the daily concentration limit of $50 \mu \mathrm{g} . \mathrm{m}^{-3}$ established by the European Air Quality Directive 2008/50/EC being surpassed several times throughout the campaigns performed.

These exceedances occurred especially during the second campaign (under the influence of south winds) and with the possible influence of other sources including residential combustion. Considering the combination of the different measurement periods, the average concentration of PM10 was $45 \mu \mathrm{g} \cdot \mathrm{m}^{-3}$ in location $\mathrm{P} 1,37 \mu \mathrm{g} \cdot \mathrm{m}^{-3}$ in $\mathrm{P} 2$ and $34 \mu \mathrm{g} \cdot \mathrm{m}^{-3}$ in $\mathrm{P} 3$, indicating a highest potential influence of port activities and other sources in location P1. During the last period of measurements, the concentrations decreased and the differential 
between concentrations in P1 and the other locations was lower (average PM10 concentration of $29 \mu \mathrm{g} . \mathrm{m}^{-3}$ in location P1, $29 \mu \mathrm{g} . \mathrm{m}^{-3}$ in P2 and $23 \mu \mathrm{g} \cdot \mathrm{m}^{-3}$ in P3). During this period, the procedures and good practices presented in Section 3 had already been implemented (e.g. keeping the piles humid and protected from wind to reduce dust emission), contributing to the reduction of possible emissions from handling and storing the petcoke.

For the remaining species measured, the PAH values were found to be within the values measured in European rural areas [16] and the heavy metals were also generally low and below the limit of target values defined in the legislation for $\mathrm{Pb}, \mathrm{As}, \mathrm{Cd}$ and $\mathrm{Ni}$. Considering other metals with possible association with petcoke emissions (e.g. vanadium), the average concentrations were within ranges observed in urban or rural areas in Europe [17-19].

\section{WIND TUNNEL MODELLING}

The physical modelling was carried out in the open-circuit wind tunnel, located at the Department of Environment and Planning of the University of Aveiro. This wind tunnel is $12 \mathrm{~m}$ long and has a model test section of $6.5 \mathrm{~m} \times 1.5 \mathrm{~m} \times 1.0 \mathrm{~m}(\mathrm{~L} \times \mathrm{W} \times \mathrm{H})$. It is typically used for physical modelling of urban flows and air quality [13]. The simulated boundary layer is achieved using vertical turbulence-generating spires at the wind tunnel entrance and a fetch of roughness elements located downwind from the spires.

In this study, the wind tunnel was used to assess the construction upwind from the petcoke pile of different barrier configurations. The study domain was focused on the petcoke stockpile to understand the microscale behaviour of the turbulent flow dynamics and its effect on petcoke emissions reduction considering the mitigation measures. A stockpile was created with the equivalent configuration to the ones in the SGT of the port of Aveiro, for discharges of about 10,000 tons of petcoke, according to the guidelines given by the port of Aveiro Administration. The dimension of each study pile was scaled at 1/127 to represent a size of $95 \mathrm{~m}$ length $\times 33 \mathrm{~m}$ wide $\times 7 \mathrm{~m}$ height. In order to create the piles for the tests, low granulometry petcoke samples were used to form the pile, since these have the greatest dispersion potential.

Several simulations were performed to determine the main characteristics, i.e. dimensions and configuration, of the barrier that would lead to an effective minimization of petcoke emission to the atmosphere. Six different spatial configurations were tested in the wind tunnel for placement of the barrier. The position and dimension of the barrier for each configuration (' $\mathrm{A}$ ' to ' $F$ ') is represented in Fig. 2.

For each of these configurations, a set of different simulations was carried on accounting for different wind directions (N, S and NW) and wind speeds (approx. 3, 7 and $11 \mathrm{~m} . \mathrm{s}^{-1}$ ). These variables represent typical wind conditions and the most critical conditions for the transport of petcoke particles to the residential area.

Each experiment had the duration of 10 minutes and the petcoke pile was weighted before and after the wind tunnel simulation. The petcoke fugitive emissions were obtained by the weight difference, considering the wind as the only responsible agent for dragging particles out of the pile and for its transport downstream. The emission reduction was determined from the loss of pile weight registered. The mass emission rates used were those calculated for the worst-case scenario in terms of potential emissions, i.e. the moisture content below $1 \%$ $(0.59 \% \pm 0.066)$. The six distinct barrier configurations were simulated in the wind tunnel and the emission reduction rate was estimated. The maximum and minimum emission reductions achieved for the distinct barrier configurations are presented in Table 1. Figure 3 shows the pile in the wind tunnel after the experiments for the $11 \mathrm{~m} \cdot \mathrm{s}^{-1}$ northwest wind conditions, in the configuration F. The experiment in which no barrier was placed was the scenario where 
A
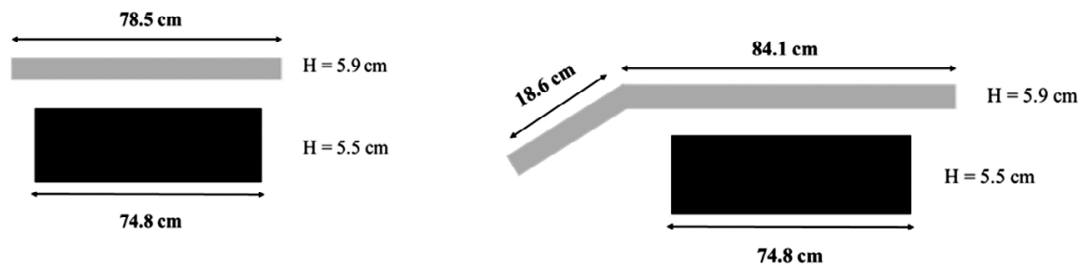

B

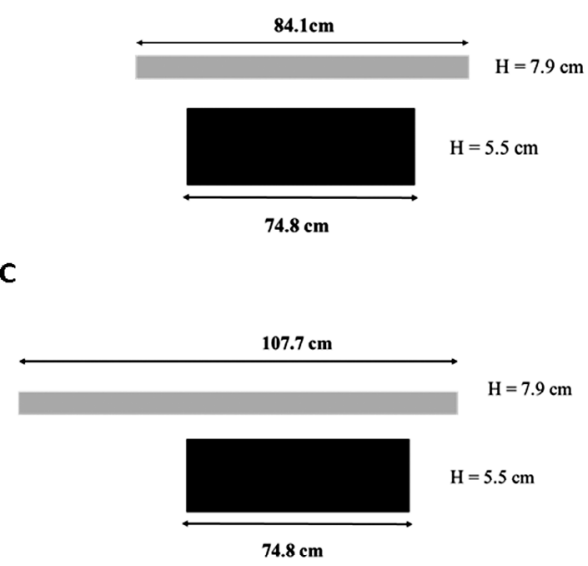

C
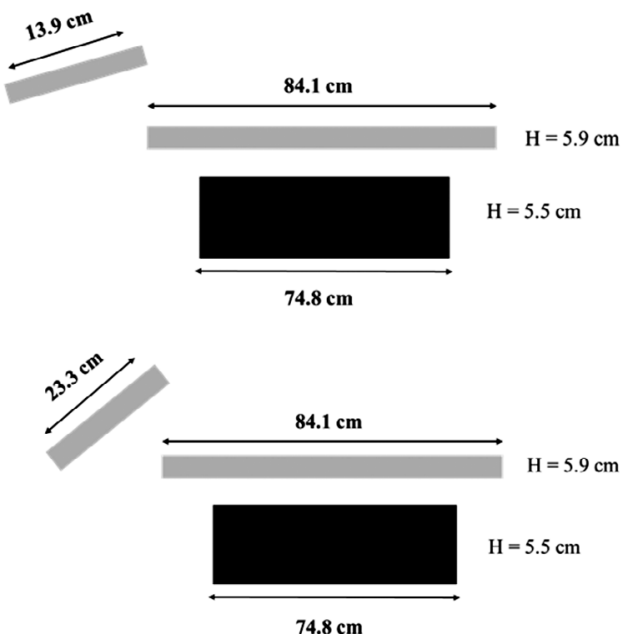

Figure 2: Schematic representation for the six different barrier configurations tested and their respective dimensions (black - stockpile and grey - barrier). The thickness of the barrier was $1.9 \mathrm{~cm}$ in all configurations.

the greater emissions were registered (45\%), with the petcoke pile even losing its original trapezoidal configuration. Compared to the situation with a barrier, there was a reduction of $74 \%$ on petcoke emission. Figure 4 shows images taken after the wind tunnel experiments for the $11 \mathrm{~m} . \mathrm{s}^{-1}$ north wind conditions, in the configuration B.

For the highest speed and north wind direction, which represents one of the most commonly registered conditions in this region, $88 \%$ of emission reduction was achieved. Moreover, considering this higher wind speed, the best results were achieved exactly for the $\mathrm{N}$ direction

Table 1: Minimum and maximum emission reductions (\%) achieved for the six different barrier configurations tested.

\begin{tabular}{ccc} 
Configuration & $\begin{array}{c}\text { Minimum emission reduction } \\
\left.\text { (NW direction and 11 } \mathrm{m} . \mathrm{s}^{-1}\right)\end{array}$ & $\begin{array}{c}\text { Maximum emission reduction (N, } \\
\text { NW and S directions and 3 } \mathrm{m}^{-1} \text { ) }\end{array}$ \\
\hline A & $8 \%$ & $100 \%$ \\
B & $21 \%$ & $100 \%$ \\
C & $10 \%$ & $100 \%$ \\
D & $58 \%$ & $100 \%$ \\
E & $63 \%$ & $100 \%$ \\
F & $74 \%$ & $100 \%$ \\
\hline
\end{tabular}




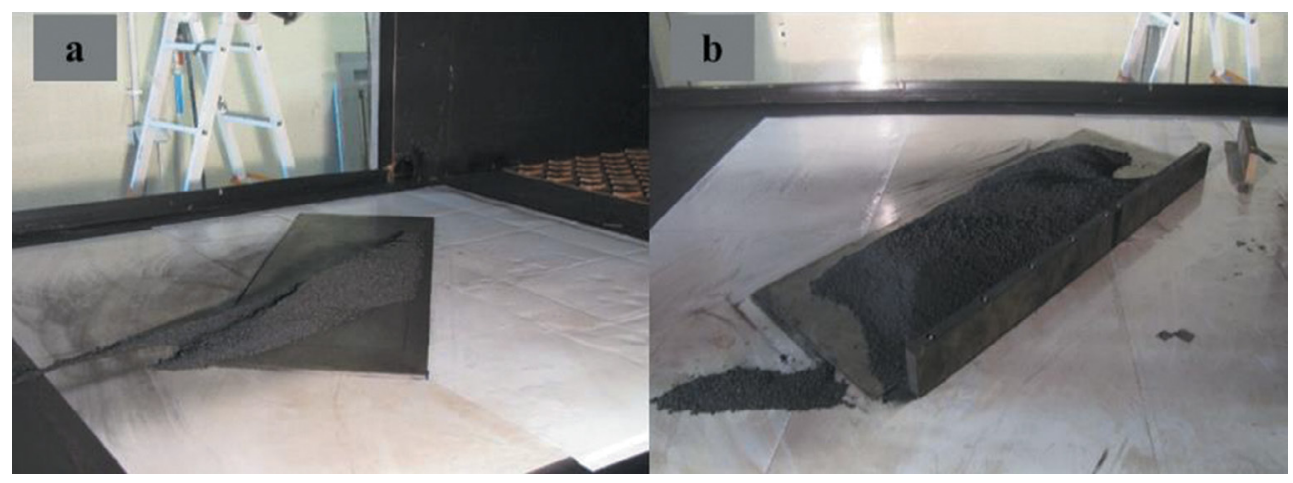

Figure 3: (a) Southeast perspective of the petcoke pile for no barrier placement experiments; (b) East perspective of petcoke pile for barrier placement scenario, both after the $11 \mathrm{~m} \cdot \mathrm{s}^{-1}$ and northwest wind experiment.

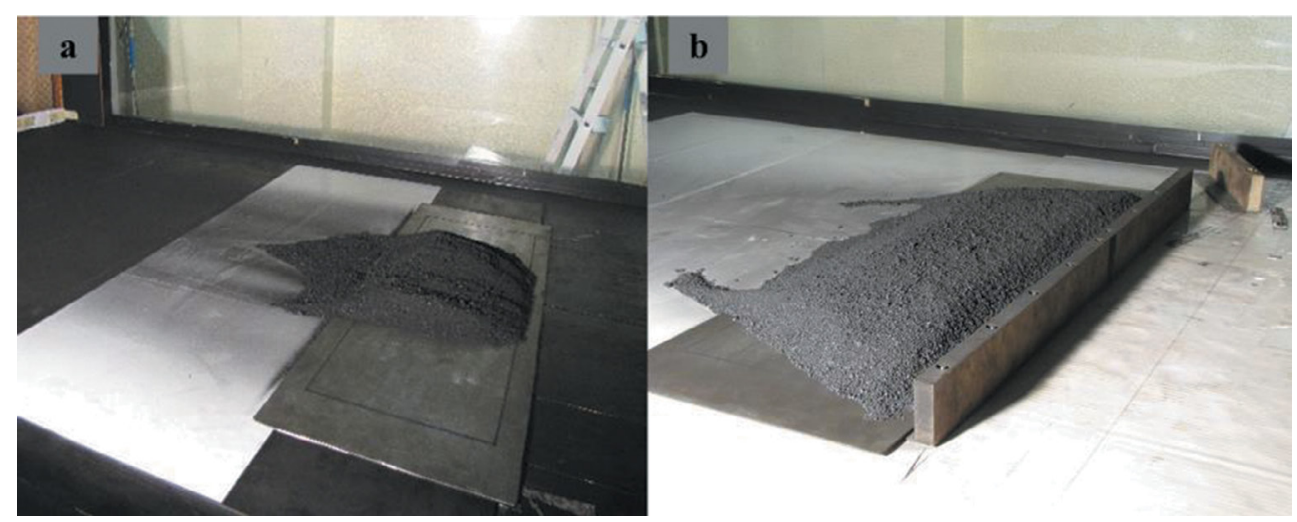

Figure 4: (a) East perspective of the petcoke pile for no barrier placement scenario; (b) East perspective of petcoke pile for barrier placement scenario, both after the $11 \mathrm{~m} . \mathrm{s}^{-1}$ and north wind experiment.

wind, which is a very promising result in terms of reducing fugitive particles endangering the residential neighbourhood (only $5.14 \%$ of the pile was dragged by the wind). Table 2 presents the main results of the petcoke dust emissions, with and without the placement of the barrier upwind from the pile, for the different configurations defined. A comparison of gained emission reduction is made between the sets with and without barriers.

Results from the physical modelling approach showed that using an upwind barrier led to a very positive impact on petcoke dust emissions, with considerable reduction for the tested configurations (up to 100\%). For the three wind directions tested, and for the lower wind speed $\left(3 \mathrm{~m} . \mathrm{s}^{-1}\right)$, the results indicate that the proposed barrier showed the capacity to eliminate petcoke dust emissions. Regarding the other wind speeds scenarios, the placement of the barrier proved to be more efficient for north winds, achieving emission reductions of $71 \%$ for $7 \mathrm{~m} . \mathrm{s}^{-1}$ wind speed and $88 \%$ for $11 \mathrm{~m} . \mathrm{s}^{-1}$ wind speed. Despite being less efficient for northwest winds, the tested barrier still could reduce emissions of approximately $60 \%$ for $7 \mathrm{~m} . \mathrm{s}^{-1}$ wind speed and $74 \%$ for $11 \mathrm{~m} \cdot \mathrm{s}^{-1}$ wind speed. 
Table 2: Petcoke emission reduction (\%) for the different wind conditions tested using the optimum configuration $\mathrm{F}$.

\begin{tabular}{crccr}
\hline Wind direction & $\begin{array}{c}\text { Velocity } \\
\left({\left.\mathrm{m} . \mathrm{s}^{-1}\right)}^{2}\right.\end{array}$ & $\begin{array}{l}\text { Fugitive particles } \\
\text { fraction - without } \\
\text { barrier (\%) }\end{array}$ & $\begin{array}{l}\text { Fugitive particles } \\
\text { fraction - with barrier (\%) }\end{array}$ & $\begin{array}{l}\text { Emission } \\
\text { reduction (\%) }\end{array}$ \\
\hline \multirow{2}{*}{$\mathrm{NW}$} & 3 & 0.020 & 0.000 & 100 \\
& 7 & 4.216 & 1.688 & 59 \\
& 11 & 45.605 & 11.765 & 74 \\
$\mathrm{~N}$ & 3 & 0.016 & 0.000 & 100 \\
& 7 & 0.375 & 0.109 & 70 \\
& 11 & 43.846 & 5.140 & 88 \\
$\mathrm{~S}$ & 3 & 0.016 & 0.000 & 94 \\
& 7 & 0.375 & 0.019 & 74 \\
\hline
\end{tabular}

For south wind, the barrier also had a positive effect in maintaining the dust particles in the surroundings of the pile. It is worth noting that the described experimental study was performed for very low petcoke moisture contents, which leads to higher emissions than samples with a higher moisture content typically stored in the SGT.

\section{CFD NUMERICAL MODELLING}

In this study, the commercial computational fluid dynamics (CFD) model FLUENT was applied to a set of baseline numerical simulations. These baseline simulations were performed to assess the impacts of storage and transport of petcoke on local air quality, allowing a spatial extended characterization of the air quality problem, previously identified by the population. Furthermore, the CFD model was used to perform a set of simulations - mitigation scenarios - to assess the effectiveness of the implementation of an upstream barrier from the petcoke stockpile.

The ANSYS FLUENT is a multi-purpose commercial CFD software tool available, including well-validated physical models able to provide accurate results across a wide range of multidisciplinary physics application [20]. ANSYS FLUENT has been applied in the simulation of flow and dispersion of fluids and particles within confined and open complex geometries in different scientific and technical domains. The FLUENT suitability for urban air quality modelling was previously evaluated [21, 22]. In this study, the ANSYS FLUENT 6.3.26 was applied to the numerical simulation of the turbulent flow dynamics and the dispersion of petcoke fugitive dust emissions, using the Reynolds-Averaged Navier-Stokes (RANS) approach with a first order $\mathrm{k}-\varepsilon$ turbulence closure scheme. The numerical simulations were performed with an hourly time basis assuming steady-state flow conditions. The inflow and boundary conditions were defined based on the typical meteorological data discussed in Section 2. The inflow conditions were defined using the theoretical log-wind profile.

\subsection{Baseline simulations}

The computational domain was designed using the Gambit processor applying an unstructured mesh. In the baseline simulations, the computational domain encompasses the SGT terminal, as well as a first row of buildings of the residential area, located nearest the terminal. 
Table 3: Maximum concentrations obtained within the computational domain, the residential and the industrial area.

\begin{tabular}{ccccc}
\hline \multirow{2}{*}{ Wind speed $\left(\mathrm{m}^{-\mathrm{s}^{-1}}\right)$} & Wind direction & \multicolumn{3}{c}{ Maximum concentration $\left(\mu \mathrm{g} . \mathrm{m}^{-3}\right)$} \\
\cline { 3 - 5 } & & Domain & Residential & Industrial \\
\hline 1.3 & $\mathrm{NW}$ & 100 & $<1$ & 12 \\
11 & $\mathrm{NW}$ & 500 & $<1$ & 19 \\
1.3 & $\mathrm{~N}$ & 300 & 9 & $<1$ \\
11 & $\mathrm{~N}$ & 600 & 9 & $<1$ \\
\hline
\end{tabular}

The dimensions of the computational domain are $3 \mathrm{~km} \times 2.5 \mathrm{~km}$, and the grid resolution is $1 \mathrm{~m} \times 1 \mathrm{~m}$. The main goal of the baseline CFD numerical simulations was to assess the impacts of particulate matter dispersion from the petcoke stockpile on local air quality. For that purpose, a set of numerical simulations of the turbulent flow dynamics was carried out considering two distinct wind directions, north and northwest, and several wind speeds ranging from very low wind speed conditions $\left(1.3 \mathrm{~m} . \mathrm{s}^{-1}\right)$ to high wind speed conditions $\left(11 \mathrm{~m} . \mathrm{s}^{-1}\right)$. After the flow dynamics simulation, the transport of particles from the petcoke stockpile was evaluated applying the Lagrangian particle tracking approach available on ANSYS FLUENT 6.3.26 version. The baseline simulation results show that wind blowing from north directions leads to highest concentrations downstream near the petcoke stockpile, while northwest directions conduct to transport of particles to the industrial area. Table 3 presents the maximum concentrations obtained within the computational domain, the residential area and the industrial area.

The petcoke fugitive emissions are driven by the turbulent flow downstream the pile along the wake over the recirculation areas. The very low wind speeds found in these areas promote the accumulation of particles. Thus, the area within the domain recording the maximum concentration is located downstream near the petcoke pile. The contribution to the local air quality in the surroundings of the seaport ranges from $9 \mu \mathrm{g} \cdot \mathrm{m}^{-3}$ in the residential areas up to $19 \mu \mathrm{g} . \mathrm{m}^{-3}$ in the industrial areas. Additionally, the numerical results indicate that north winds drive the particulate matter to the residential area, while northwest winds conduct the particles to the industrial area. Interestingly, north wind direction is substantially unfavourable to particles dispersion around the piles and this may be critical for the exposure of harbour staff.

\subsection{Mitigation scenarios simulations}

In order to evaluate the effectiveness of the implementation of an upstream barrier from the petcoke stockpile, the CFD model FLUENT was used to perform a new set of numerical simulations. A new computational domain of $500 \mathrm{~m} \times 500 \mathrm{~m}$ includes the petcoke stockpile and the upstream barrier with the configuration F of Fig. 4 - the optimal configuration identified by the wind tunnel simulations. Figure 5 shows, as an example, the top view of particles' trajectories speed within the computational domain for the wind blowing from NW with a wind speed of $11 \mathrm{~m} \cdot \mathrm{s}^{-1}$.

The effectiveness of the barrier implementation is quantified by comparing the reduction of the petcoke dust transported from the stockpile in the mitigation scenarios simulations compared with the baseline results. The implementation of an upstream barrier from the petcoke stockpile reduces the wind intensity over and around the pile, leading to a reduction of particle matter transported of approximately $68 \%$, in the case of high wind speed $\left(11 \mathrm{~m} . \mathrm{s}^{-1}\right)$, either 


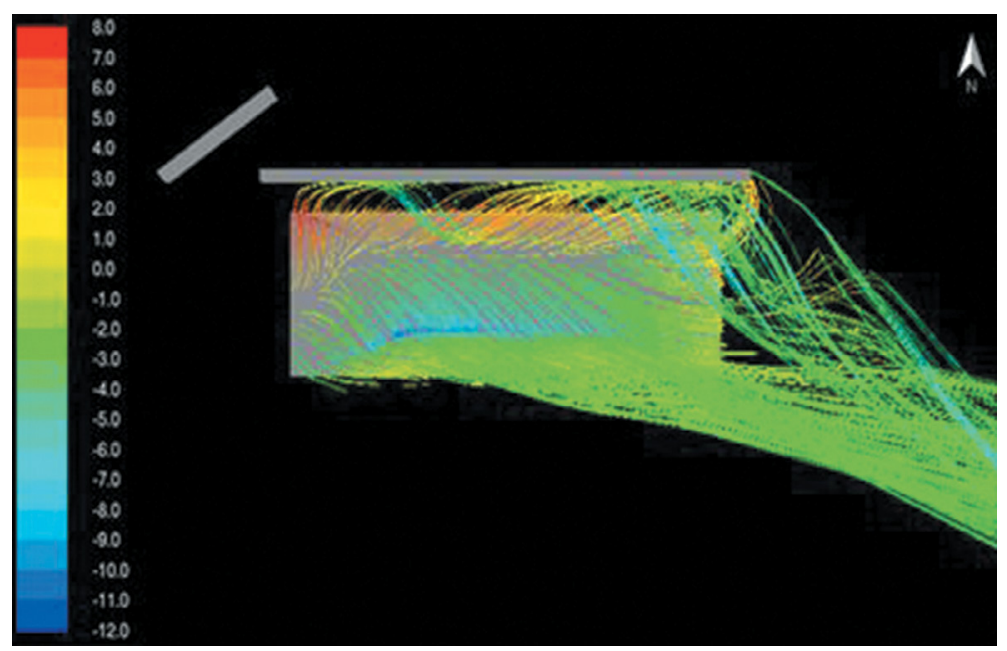

Figure 5: Top view of particles' trajectories for the simulation with the upstream barrier from the pile with northwest direction and wind speed of $11 \mathrm{~m} . \mathrm{s}^{-1}$ as inflow conditions. The colour scale represents the trajectories' speed in $\mathrm{m} . \mathrm{s}^{-1}$.

from north or northwest directions. The numerical results are in good agreement with the physical results, since in Section 5 is presented a reduction of $88 \%$ for north and $74 \%$ for northwest directions. The implementation of the upstream barrier led to an effective reduction of the numerical particles transported up to the residential area, for both wind direction situations. Following this, the numerical results confirm the implementation of the upstream barrier as an optimum mitigation measure to protect the urban community located south from the SGT.

\section{CONCLUSIONS}

This article focuses on the studies carried out to investigate and assess the best air quality management approach to address the concerns raised by a population in regard to the impact of petcoke dust dispersion from the near port of Aveiro (Portugal). This procedure included local air quality monitoring, adoption of preliminary non-technical mitigation measures and two complementary modelling approaches that evaluated the implementation of a protection barrier: physical (wind tunnel) and numerical (CFD).

The experimental air quality field campaigns show that under particular meteorological conditions the atmospheric concentration of PM10 could be significantly high, particularly in the second campaign. However, during the last period of measurements, the pollution levels decreased and this could be related with a change in procedure when handling and storing the petcoke, following the suggestions of keeping the piles more humid and protected from wind, altering the way petcoke is offloaded and releasing the petcoke closer to the ground, to reduce dust emissions.

The modelling study aimed at determining the optimal dimensions and location of a windbreaking barrier to minimize the petcoke dust emission and its transport from the port to the town of Gafanha da Nazaré, located S-SE of the SGT. Results from the wind tunnel modelling showed that the barrier can effectively reduce the petcoke dust emissions for the wind directions tested $(\mathrm{N}, \mathrm{NW}$ and $\mathrm{S})$ when low speed wind regime applies $\left(3 \mathrm{~m} \cdot \mathrm{s}^{-1}\right)$. In the 
residential areas, for the most critical wind directions ( $\mathrm{N}$ and $\mathrm{NW})$, reductions on emission of $71 \%$ and $60 \%$ were obtained for the case of $7 \mathrm{~m} . \mathrm{s}^{-1}$ wind speed. For stronger winds $\left(11 \mathrm{~m} . \mathrm{s}^{-1}\right)$, the reduction on petcoke dust emissions was even higher, reaching approximately $88 \%$ for north winds and $74 \%$ for northwest winds. The numerical modelling results reinforced that north winds drive the particulate matter to the residential area and the implementation of the barrier could efficiently mitigate the problem.

Based on the obtained results, it is possible to conclude that placing the tested barrier represents in fact a viable and effective solution to reduce the dispersion and transport of the dust emissions from petcoke pile for critical wind conditions. The barrier has been implemented on a real scale and monitoring campaigns are currently being carried out to assess its effectiveness, in combination with good practices on (un)loading and storing petcoke in the port of Aveiro. The analyses of these experimental results will provide evidences on the actual improvement and the perception of it by the population.

\section{ACKNOWLEDGEMENTS}

The authors wish to thank the financial support of FEDER through the COMPETE Programme and the national funds from FCT - Science and Technology Portuguese Foundation for financing the AIRSHIP project (PTDC/AAG-MAA/1581/2014). The authors are also grateful to the APA for promoting the work and allowing the results to be disseminated.

\section{REFERENCES}

[1] ESPO - European Sea Ports Organisation, Top Environmental Priorities of European Ports for 2013. An Analysis Taking Port Size and Geography into Consideration. ESPO, Brussels, 2013.

[2] CRS (Congressional Research Service), Petroleum Coke: Industry and Environmental Issues. CRS Report R43263, Washington, D.C., 25 p, 2013.

[3] Dourson, M.L., Chinkin, L.R., MacIntosh, D.L., Finn, J.A., Brown, K.W., Reid, S.B. \& Martinez, J.M., A case study of potential human health impacts from petroleum coke transfer facilities. Journal Air Waste Management Association, 66, pp. 1061-1076, 2016. DOI: 10.1080/10962247.2016.1180328.

[4] McKee, R.H., Herron, D., Beatty, P., Podhasky, P., Hoffman, G.M., Swigert, J., Lee, C. \& Wong, D., Toxicological assessment of green petroleum coke. International Journal Toxicology, 33, pp. 156S-167S, 2014. DOI: 10.1177/1091581813504187.

[5] Caruso, J.A., Zhang, K., Schroeck, N.J., McCoy, B. \& McElmurry, S.P., Petroleum coke in the urban environment: A review of potential health effects. International Journal Environment Research Public Health, 12, pp. 6218-6231, 2015. DOI: 10.3390/ ijerph120606218.

[6] Donaldson, K, Tran, L, Jimenez, L.A, Duffin, R, Newby, D.E, Mills, N, MacNee, W $\&$ Stone, V., Combustion-derived nanoparticles: a review of their toxicology following inhalation exposure. Particle Fibre Toxicology, 21, pp. 2-10, 2005. DOI: 10.1186/17438977-2-10.

[7] EEA (European Environment Agency), Air quality in Europe - 2013 report, EEA Report No. 9/2013, Copenhagen, 112 p, 2013.

[8] Wegesser, T.C. \& Last, J.A., Lung response to coarse PM: bioassay in mice. Integrative Pharmacology, Toxicology and Genotoxicology, 230, pp. 159-166, 2008. DOI: 10.1016/j.taap.2008.02.013. 
[9] Roskill Information Services Head Office. https://roskill.com/product/petroleum-cokeglobal-industry-markets-outlook-7th-edition-2015 (accessed February 2016).

[10] IndexMundi, http://www.indexmundi.com/trade/imports/?subchapter=2713 (accessed 2016, 2016).

[11] CIMPOR Enterprise, http://www.cimpor-portugal.pt/ (accessed 2016, 2014).

[12] Gupta, A.K., Gupta, S.K. \& Patil, R.S., Environmental management plan for port and harbour projects. Clean Technologies and Environmental Policy, 7(2), pp. 133 -141, 2005. DOI: 10.1007/s10098-004-0266-7.

[13] Borrego, C., Costa, A. M., Amorim, J., Santos, P., Sardo, J., Lopes, M. \& Miranda, A. I., Air quality impact due to scrap-metal handling on a sea port: a wind tunnel experiment. Atmospheric Environment, 41, pp. 6396-6405, 2007. DOI: 10.1016/j. atmosenv.2007.01.022.

[14] Borrego, C., Coutinho, M., Costa, A.M., Ginja, J., Ribeiro, C., Monteiro, A., Ribeiro, I., Valente, J., Amorim, J.H., Martins, H., Lopes, D. \& Miranda, A.I., Challenges for a new air quality directive: The role of monitoring and modelling techniques. Urban Climate, 14, pp. 328-341, 2015. DOI: 10.1016/j.uclim.2014.06.007.

[15] IDAD (Institute of Environment and Development), Avaliação da Qualidade do Ar na Envolvente do Porto de Aveiro, IDAD report No. R074.15-14/05.05, Aveiro, 100 pages, 2015.

[16] Commission E., 2001 Commission E. Ambient Air Pollution by Polycyclic Aromatic Hydrocarbons (PAH), 2001.

[17] WHO (2000). Air quality guidelines for Europe. WHO Regional Office. Copenhagen.

[18] Rodriguez, S., Querol, X., Alasteuy, A., Viana, M., Alarcón, M., Mantilla, E., Ruiz, C. R. Comparative PM10-PM2.5 source contribution study at rural, urban and industrial sites during PM episodes in Eastern Spain. Science of the Total Environment, 328, 95-113, 2004. DOI: 10.1016/S0048-9697(03)00411-X.

[19] Moreno, T., Querol, X., Alastruey, A., Viana, M., Salvador, P., Campa, A. S., Artiñano, B., Rosa, J., Gibbons, W. Variations in atmospheric PM trace metal content in Spanish towns: Illustrating the chemical complexity of the inorganic urban aerosol cocktail. Atmospheric Environment, 40, 6791-6803, 2006. DOI: 10.1016/j.atmosenv.2006.05.074.

[20] ANSYS FLUENT, 14.5. User's and theory guide. Canonsburg, Pennsylvania, USA: ANSYS, Inc., 2014.

[21] Borrego, C., Tchepel, O., Costa, A.M., Amorim, J.H. \& Miranda, A.I., Emission and dispersion modelling of Lisbon air quality at local scale. Atmospheric Environment, 37, pp. 5197-5205, 2003. DOI: 10.1016/j.atmosenv.2003.09.004.

[22] Martins, A., Cerqueira, M., Ferreira, F., Borrego, C. \& Amorim, J.H., Lisbon air quality - evaluating traffic hot-spots. International Journal Environmental Pollution, 39, 306-320, 2009. DOI: 10.1504/IJEP.2009.028693. 